\title{
HUBUNGAN INTENSITAS PENGGUNAAN GADGET DENGAN KELUHAN COMPUTER VISION SYNDROME PADA SISWA-SISWI DI SMPN 4 DENPASAR
}

\author{
${ }^{1}$ I Gusti Agung Istri Agung Gayatri, ${ }^{2}$ Luh Mira Puspita, ${ }^{3}$ Ni Kadek Ayu \\ Suarningsih \\ ${ }^{123}$ Program Studi Sarjana Keperawatan dan Profesi Ners Fakultas Kedokteran Universitas Udayana \\ Alamat Korespondensi: istrigayatri@gmail.com
}

\begin{abstract}
ABSTRAK
Remaja diketahui merupakan pengguna gadget terbanyak saat ini. Rata-rata remaja memiliki intensitas penggunaan gadget kurang lebih 5 jam dan semakin lama dapat meningkat. Penggunaan gadget yang berlebih dapat menimbulkan keluhan Computer Vision Syndrome (CVS) seperti kelelahan serta gangguan mata. Penelitian ini bertujuan untuk mengetahui hubungan intensitas penggunaan gadget dengan keluhan CVS pada siswa-siswa SMPN 4 Denpasar. Metode yang digunakan pada penelitian ini ialah cross-sectional dengan menggunakan instrumen pengumpulan data berupa kuisioner. Penelitian ini menggunakan teknik sampling berupa simple random sampling dan menetapkan 179 siswa sebagai sampel penelitian. Hasil menunjukkan bahwa hampir sebagian responden memiliki intensitas penggunaan gadget dalam kategori rendah $(43 \%)$ dan responden terbanyak memiliki keluhan CVS dalam kategori sedang (39\%). Terdapat hubungan antara intensitas penggunaan gadget dengan keluhan CVS ( $\mathrm{p}$ value $=0,05 ; \mathrm{a}=0,05 ; \mathrm{r}=0,086$ ). Hubungan tersebut bermakna positif lemah yang menunjukkan bahwa semakin tinggi nilai intensitas penggunaan gadget maka semakin tinggi keluhan CVS yang dirasakan siswa-siswi di SMPN 4 Denpasar.
\end{abstract}

Kata Kunci: computer vision syndrome; intensitas gadget; siswa

\begin{abstract}
Nowadays, teenagers are known to be the most gadget users. Averagely, teenagers have the intensity of using gadgets for about 5 hours and it can still be increasing. Excessive use of gadgets can lead to complaints of Computer Vision Syndrome (CVS) such as fatigue and eye disorders. This research is aimed to explore the connection between the intensity of gadget use with the computer vision syndrome complain in the students of smpn 4 Denpasar. The method used in this research is cross-sectional with the instrument of collecting data in the form of questionnaire. This research uses sampling technique in the form of simple random sampling and choose 179 students as research sample. The results shows that almost half of the respondent have gadget use intensity in low category $(43 \%)$ and the most respondents have CVS complain in middle category $(39 \%)$. The connection between gadget use intensity to the CVS complaint is ( $p$ value $=0,05 ; \mathrm{a}=0,05 ; \mathrm{r}=0,086)$. The connection means weak positive that shows that the higher the gadget use intensity is, the higher the CVS complaint is felt by the students of SMPN 4 Denpasar too r.
\end{abstract}

Keyword: computer vision syndrome; gadget intensity; students 


\section{PENDAHULUAN}

sesuai Kemajuam teknologi berjalan pengetahuan (Ngafifi, 2014). Salah satu teknologi yang diminati oleh masyarakat yaitu gadget. Gadget merupakan barang elektronik yang mempermudah kehidupan manusia. (Fahdian, Agus \& Mansur, 2018).

Indonesia menduduki posisi kelima besar dunia dalam penggunaan gadget terbanyak. Diprediksi memiliki rata-rata pertumbuhan hampir $70 \%$ tiap tahunnya sejak 2010 sampai 2013 untuk peningkatan pasar gadget.

Keberadaan gadget dapat mempermudah segala kebutuhan dan kegiatan remaja, salah satunya untuk mengakses informasi yang dapat menambah wawasan, sebagai gaya hidup, dan eksistensi diri, karena gadget memiliki aplikasi dan pembaharuan yang disukai banyak orang dan membuat hidup lebih mudah. Banyak remaja yang memanfaatkan penggunaan berbagai jenis gadget di sekolah, seperti smartphone, laptop, dan tablet.

Penelitian yang dilakukan oleh Manumpil, Onibala dan Ismanto 2015 ditemukan sebanyak $71,8 \%$ remaja menggunakan gadget dengan durasi $<11$ jam per hari. Penelitian serupa yang dilakukan Putra 2017 mayoritas remaja pengguna gadget dengan durasi $<5$ jam per hari dan durasi tersebut semakin meningkat pada hari sabtu dan minggu.

Penelitian menyebutkan adanya peningkatan penggunaan gadget lebih dari durasi ideal dapat menimbulkan beberapa keluhan pada remaja yang berhubungan dengan kesehatanannya. Penelitian dari Andriana, Rozalina dan Djohar (2018) menyatakan penggunaan gadget berlebihan dapat menimbulkan berbagai masalah kesehatan. Dampak fisik yang terjadi akibat dari penggunaan gadget yang melebihan batas ideal salah satunya pada mata. Lebih dari $90 \%$ pengguna gadget mengalami gejala pengelihatan seperti mata lelah, pengelihatan buram, dan mata kering yang termasuk ke dalam keluhan Computer Vision Syndrome (CVS).

American

Optometric

Association (AOA) mendefinisikan CVS sebagai kumpulan gejala yang terjadi pada mata yang disebabkan oleh penggunaan komputer, tablet, handphone atau alat elektronik lainnya dalam waktu yang cukup lama (American Optometric Association, 2015). CVS sering dianggap sebagai sesuatu yang tidak mengancam nyawa, hal ini menyebabkan ketidakpedulian remaja dalam memeriksakan kesehatan mata pada saat merasakan keluhan, sehingga jika CVS tidak segera diatasi maka akan menghambat aktivitas sehari-hari, penurunan produktivitas, peningkatan tingkat kesalahan dalam bekerja, dan penurunan kualitas hidup seseorang.

Hampir 60 juta orang diperkirakan mengalami CVS secara global dan 1 juta kasus terjadi setiap tahunnya. Banyaknya waktu yang dihabiskan remaja di sekolah membuat sekolah memiliki pengaruh yang besar dalam membentuk perilaku remaja. Rata-rata sekolah yang bertempat di Denpasar terdapat fasilitas internet yang disediakan oleh pihak sekolah, hal ini dibuat untuk mempermudah para remaja untuk mendapatkan informasi dari internet untuk membantu mereka dalam belajar dan untuk mempermudah mereka mencari informasi untuk menambah wawasan.

Dari hasil studi pendahuluan dapat disimpulkan rata-rata penggunaan gadget pada pada siswa-siswi yaitu > 4 
jam per hari dimulai dari bangun tidur dan istirahat malam. Rata-rata seluruh siswa-siswi membawa gadget sedikitnya dua jenis yaitu smartphone dan laptop, gadget biasanya digunakan pada jam istirahat ataupun pada jam pelajaran kosong, Hasil dari wawancara menyatakan rata-rata siswa-siswi menggunakan gadget untuk media sosial, game online, selfie, dan juga untuk komunikasi.

Penggunaan gadget secara aktif ini menyebabkan siswa-siswi berisiko tinggi untuk terkena CVS. Keluhan yang sering dialami oleh siswa-siswi yang diutarakan saat wawancara adalah mata kering, mata gatal, mata merah, dan sakit kepala. Berdasarkan hasil dari studi pendahuluan, sekolah yang Penggunaan gadget secara aktif ini menyebabkan siswa-siswi berisiko tinggi untuk terkena CVS. Keluhan yang sering dialami oleh

\section{METODE PENELITIAN}

Penelitian ini merupakan penelitian kuantitatif dengan jenis penelitian deskriptif korelasional. Rancangan penelitian yang digunakan dalam penelitian ini yaitu crosssectional. Penelitian dilakukan di SMPN 4 Denpasar.

Populasi dalam penelitian ini adalah siswa-siswi yang duduk di kelas VIII di SMPN 4 Denpasar yang berjumlah 323 orang. Penentuan sampel dilakukan dengan menggunakan metode probability sampling dengan teknik simple random sampling. Jumlah sampel dihitung dengan rumus Slovin yaitu sebanyak 179 orang yang memenuhi kriteria inklusi dan eksklusi.

Instrumen penelitian yang digunakan adalah kuesioner data demografi, kuesioner intesitas penggunaan gadget, dan kuesioner keluhan CVS. Kuesioner intensitas penggunaan gadget yang dipergunakan siswa-siswi yang diutarakan saat wawancara adalah mata kering, mata gatal, mata merah, dan sakit kepala. Berdasarkan hasil dari studi pendahuluan, sekolah yang memiliki risiko lebih besar sesuai dengan pernyataan yang diberikan oleh beberapa siswa-siswi yang telah diwawancara adalah SMPN 4 Denpasar. Pada pernyataan yang diberikan saat wawancara beberapa siswa-siswi menyatakan menggunakan gadget $>4$ jam perharinya dan mengalami peningkatan apabila tidak ada guru yang mengajar, tidak ada tugas dari sekolah ataupun di hari libur. Keluhan yang dialami hampir sama dengan siswa-siswi lainnya namun keluhan yang dirasakan seperti mata kering, gatal, mata merah hingga pengelihatan kabur lebih sering dirasakan.

peneliti dalam pengumpulan data merupakan kuesioner yang mengadopsi dari Horrigan, J.B (2002) dan Meirianto, MT (2018) serta modifikasi oleh peneliti, aspek yang dinilai dari kuesioner adalah aspek frekuensi dan lama mengakses dari gadget. Kuesioner keluhan CVS yang dipergunakan peneliti dalam pengumpulan data merupakan kuesioner yang mengadopsi dari Rathore (2017). Kuesioner terdiri dari 20 item pertanyaan yang terdiri dari 4 aspek yaitu aspek astenopia, aspek masalah permukaan okuler, aspek masalah visual, dan aspek masalah ekstra ocular dengan nilai minimal 20 dan nilai maksimal 80. Kuesioner keluhan CVS telah diuji pada 35 responden kelas VIII di SMPN 10 Denpasar, menghasilkan 7 item gugur dikarenakan skor validitas item tersebut berada di bawah nilai 0,151 . Item-item yang gugur tersebut adalah $2,8,10,11$, 12, 17 dan 19. Nilai Alpha Cronbach 
didapatkan sebesar 0,726 dengan indeks diskriminasi item bergerak dari 0,151 hingga 0,679 .

Penelitian ini telah melalui uji kelayakan etik (ethicall clearance) dari Komite Etik Penelitian Fakultas Kedokteran Universitas Udayana/RSUP Sanglah nomor 1810/UN14.2.2.VII.14/LP/2019 serta telah mendapat ijin dari pihak terkait. Data dikumpulkan dengan memberikan kuesioner kepada responden. Pengisian kuesioner dilakukan selama 30 menit dengan pengawaan oleh peneliti. Data yang telah dikumpulkan kemudian di tabulasi dan dianalisis. Analisis yang digunakan yaitu analisis univariat untuk menggambarkan variabel penelitian. Analisis bivariat digunakan untuk mengetahui hubungan variabel dependent terhadap variabel independent. Uji Spearman Rank digunakan karena data dinyatakan tidak terdistribusi normal.

\section{HASIL PENELITIAN}

Tabel 1 Distribusi Frekuensi Karakteristik $(n=179)$

\begin{tabular}{ccc}
\hline Karakteristik Responden & Frekuensi (n) & Persentase (\%) \\
\hline Umur & & $25,7 \%$ \\
a. 13 tahun & 46 & $64,8 \%$ \\
b. 14 tahun & 116 & $9,5 \%$ \\
c. 15 tahun & 17 & $\mathbf{1 0 0 , 0 \%}$ \\
Total & $\mathbf{1 7 9}$ & \\
Jenis Kelamin & & $53,6 \%$ \\
a. Laki-laki & 96 & $46,4 \%$ \\
b. Perempuan & 83 & $\mathbf{1 0 0 , 0 \%}$ \\
Total & $\mathbf{1 7 9}$ & \\
\hline Jenis Gadget & & $100,0 \%$ \\
\hline a. Smartphone & 179 & $92,7 \%$ \\
\hline Tingkat Cahaya & & $7,3 \%$ \\
\hline a. $<50 \%$ & 166 & $\mathbf{1 0 0 , 0 \%}$ \\
b. >50\% & 13 & $90,5 \%$ \\
Total & $\mathbf{1 7 9}$ & $9,5 \%$ \\
\hline Istirahat & & $\mathbf{1 0 0 , 0 \%}$ \\
\hline a. Ya & 162 &
\end{tabular}

Berdasarkan Tabel 1 didapatkan hasil bahwa dari 179 responden sebagian besar berjenis kelamin laki-laki yaitu sebanyak 92 orang $(53,6 \%)$.Usia responden rata-rata berkisar 13 tahun yaitu sebanyak 46 orang $(25,7 \%), 14$ tahun yaitu sebanyak 116 orang $(64,8$ $\%)$, dan 15 tahun yaitu sebanyak 17 orang $(9,5 \%)$, berdasarkan hasil dari distribusi frekuensi dari 179 responden didapatkan sebagian besar responden 179 orang $(100,0 \%)$ setiap harinya membawa dan menggunakan smartphone di sekolahnya dengan tingkat cahaya $<50 \%$ yaitu sebanyak 166 orang $(92,7 \%)$ dan penggunaan gadget dengan tingkat cahaya > 50\% yaitu sebanyak 13 orang $(7,3 \%)$. Sedangkan waktu istirahat responden saat penggunaan gadget didapatkan hasil 
yaitu sebanyak 162 orang $(90,5 \%)$ menyempatkan untuk beristirahat, dan 17 orang $(9,5 \%)$ tidak beristirahat saat penggunaan gadget.

Tabel 2 Hasil Distribusi Frekuensi Penggunaan Gadget pada Siswa-siswi di SMPN 4 Denpasar (n=179)

\begin{tabular}{|c|c|c|c|}
\hline Variabel & Mean \pm SD & Minimum-Maksimum & CI 95\% \\
\hline \multicolumn{4}{|l|}{ Intensitas } \\
\hline a. Durasi & $60,00 \pm 35,695$ & $15-120$ & $59,37-69,90$ \\
\hline b. Frekuensi & $7,00 \pm 2,273$ & $2-12$ & $4,46-7,13$ \\
\hline
\end{tabular}

Berdasarkan tabel 2 menunjukan bahwa nilai rerata durasi siswa-siswi menggunakan gadget yaitu 60 menit per sekali pakai atau setara dengan 1 jam dengan nilai terendah yaitu 15 menit dan nilai tertinggi 120 menit atau setara dengan 2 jam, dengan rerata frekuensi yaitu 7 kali dengan nilai terendah 2 kali dan nilai tertinggi 12 kali penggunaan dalam sehari.

Berdasarkan perhitungan rumus menggunakan nilai mean dan standar deviasi didapatkan tiga kategori yang dapat dilihat pada Tabel 3.

Tabel 3 Kategorisasi Penggunaan Gadget pada Siswa-siswi di SMPN 4 Denpasar (n=179)

\begin{tabular}{lcc}
\hline \multicolumn{1}{c}{ Kategori } & Frekuensi (f) & Presentase (\%) \\
\hline Rendah & 77 & $43 \%$ \\
\hline Sedang & 71 & $39,7 \%$ \\
\hline Tinggi & 31 & $17,3 \%$ \\
\hline Total & $\mathbf{1 7 9}$ & $\mathbf{1 0 0} \%$ \\
\hline
\end{tabular}

Berdasarkan Tabel 3 dapat dilihat bahwa dari 179 responden, sebanyak 77 responden $(43 \%)$ menggunakan gadget dengan intensitas rendah bahkan penggunaan gadget dalam kategori sedang sebanyak 71 responden $(39,7 \%)$

Tabel 4 Hasil Distribusi Keluhan CVS pada Siswa-siswi di SMPN 4 Denpasar (n=179)

\begin{tabular}{lllc}
\hline Variabel & Mean \pm SD & Minimum-Maksimum & CI 95\% \\
\hline CVS & $29,00 \pm 4,488$ & $17-39$ & $27,90-29,23$ \\
\hline
\end{tabular}

Berdasarkan Tabel 4 menunjukkan hasil bahwa rerata skor keluhan CVS pada responden adalah 29,00 dengan skor terendah yaitu 17 dan skor tertinggi yaitu 39. Hasil estimasi dalam penelitian ini menyatakan bahwa $95 \%$ diyakini nilai skor keluhan CVS berkisar dari 27,90 hingga 29,23.

Berdasarkan perhitungan rumus menggunakan nilai mean dan standar 
deviasi didapatkan lima kategori keluhan

CVS yang dapat dilihat pada Tabel 5

Tabel 5 Kategorisasi Keluhan Computer Vision Syndrome (CVS) (n=179)

\begin{tabular}{lcc}
\hline \multicolumn{1}{c}{ Kategori } & Frekuensi (f) & Presentase (\%) \\
\hline Sangat Rendah & 7 & $3,9 \%$ \\
\hline Rendah & 55 & $30,7 \%$ \\
\hline Sedang & 68 & $38,0 \%$ \\
\hline Tinggi & 48 & $26,8 \%$ \\
\hline Sangat Tinggi & 1 & $0,6 \%$ \\
\hline Total & $\mathbf{1 7 9}$ & $\mathbf{1 0 0 , 0 \%}$ \\
\hline
\end{tabular}

Berdasarkan Tabel 5 dapat dilihat bahwa dari 179 responden, sebanyak 68 responden $(38,0 \%)$ memiliki keluhan
CVS dalam kategori sedang bahkan keluhan dalam kategori tinggi didapatkan hasil 48 responden $(26,8 \%)$

Tabel 6 Hubungan Intensitas Penggunaan Gadget dengan Keluhan Computer Vision Syndrome (CVS) pada Siswa-siswi di SMPN 4 Denpasar $(\mathrm{n}=179)$

\begin{tabular}{lccc}
\hline Variabel & Median & R & P Value \\
\hline Intensitas Penggunaan Gadget & 5,00 & & 0,001
\end{tabular}

Keluhan Computer Vision Syndrome (CVS)

29,00

Tabel 6 karena nilai $\mathrm{p}<\alpha$ maka dengan demikian dapat disimpulkan bahwa hipotesis nol (Ho) ditolak dan hipotesis alternatif (Ha). Analisis data dengan menggunakan uji korelasi spearman didapatkan nilai $\mathrm{p}$ value < 0,005 yang artinya terdapat hubungan antara intensitas penggunaan gadget dengan keluhan CVS di SMPN 4 Denpasar. Kekuatan hubungan dan arah

PEMBAHASAN hubungan dapat dilihat pada nilai Correlation Coefficient yaitu bernilai 0,086 yang menyatakan kekuatan hubungan sangat lemah dan arah hubungan positif, sehingga dapat diartikan bahwa semakin tinggi intensitas penggunaan gadget maka semakin tinggi keluhan CVS pada siswasiswi di SMPN 4 Denpasar.

Hasil penelitian di SMPN 4 Denpasar menunjukan bahwa siswa

Volume 8, Nomor 4, Desember 2020 
yang berpartisipasi dalam penelitian ini sebanyak 179 responden, mayoritas membawa dan menggunakan smartphone di sekolah. Intensitas penggunaan gadget pada siswa-siswi dari 179 responden menunjukan bahwa sebanyak 77 orang (43\%) menggunakan dengan intensitas rendah sedangkan penggunaan dengan intensitas tinggi sebanyak 31 orang $(17,3 \%)$.

Faktor yang menyebabkan intensitas penggunaan dalam kategori rendah salah satunya adalah faktor lingkungan, apabila banyak orang yang menggunakan gadget, maka akan berpengaruh pada pengguna gadget lainnya yang akan membuat enggan untuk meninggalkan gadget dan akan menambah intensitas penggunaan gadget setiap sekali pemakaiannya. Begitu juga sebaliknya, apabila berada dalam lingkungan yang produktif dan atau berada di lingkungan teman sebaya yang memiliki tingkat semangat belajar yang tinggi, maka lingkungan sekitar akan mengikuti karena dianggap sebagai acuan (Nugraha, 2017).

Penggunaan gadget pada remaja cenderung pada kategori tinggi, karena usia remaja yang masih belum bisa mengendalikan diri, mudah terpengaruh dan mudah untuk mengalihkan konsentrasinya. Berbagai faktor yang mempengaruhi tingkat intensitas menggunakan gadget pada remaja salah satunya faktor internal yaitu perilaku konsumtif, perilaku ini menyebabkan siswa tidak bisa mengambil keputusan dan pertimbangan secara tepat dalam penggunaan gadget dan berakibat pada perilaku pemborosan serta menurunnya kontrol diri siswa dalam menggunakan gadget. Menurut Gardner \& Davis, (2014) Faktor sosiall penyebab meningkatnya intensitas, penggunaan gadget adalah faktor yang menggambarkan tentang kebutuhan interaksi sosial siswa, dimana remaja adalah individu yang telah memasuki tahap usia remaja akan secara bertahap menjalani proses pematangan baik secara fisik, akal, kejiwaan, sosial serta emosional.

Intensitas penggunaan gadget pada kalangan remaja, salah satunya dipengaruhi oleh individu masingmasing. Penggunaan gadget dapat memberikan dampak negatif maupun positif tergantung dari penggunaan durasi dan frekuensi dari individu. Hasil penelitian di SMPN 4 Denpasar menunjukan bahwa rerata skor keluhan CVS pada responden remaja dengan rentang usia 13 sampai dengan 15 tahun adalah 29,00. Penelitian ini sejalan dengan penelitian yang dilakukan Das \& Ghosh, (2010) yang menyebutkan bahwa usia lebih dari 40 tahun berpotensi lebih tinggi untuk mengalami keluhan CVS disebabkan oleh terjadinya perubahan anatomi dan penurunan fungsi tubuh akibat proses penuaan. Sedangkan menurut Azkadina, (2012) usia tidak berhubungan secara signifikan dengan keluhan CVS.

Durasi penggunaan, menurut Akinbinu \& Mashalla, (2013) semakin lama durasi penggunaan dari gadget dalam satu hari maka berbanding lurus dengan banyaknya gejala yang akan dirasakan terkait dengan CVS.. Hasil penelitian lainnya menunjukkan durasi paparan 6 jam di depan layar gadget mengakibatkan lebih banyak keluhan terkait CVS (Agarwal, Dishanter, \& Anshu, 2013).

Kontras yang rendah merupakan salah satu faktor dari keluhan CVS, pada hasil penelitian yang dilakukan di SMPN 4 Denpasar, hasil dari penggunaan kontras cahaya yaitu dari 179 responden $166 \quad(92,7 \%)$ menggunakan kontras $<50 \%$. Dampak dari penurunan kecerahan ini juga 
membuat layar tampak kabur sehingga membuat mata bekerja lebih ekstra untuk memfokuskan apa yang terlihat pada layar.

Hasil penelitian yang dilaksanakan di SMPN 4 Denpasar menunjukkan bahwa terdapat hubungan antara intensitas penggunaan gadget dengan keluhan Computer Vision Syndrome (CVS) dengan arah hubungan positif dan kekuatan hubungan sangat lemah. Durasi dan frekuensi penggunaan gadget merupakan salah satu faktor yang mempengaruhi tingkat keluhan CVS yang dialami remaja (Rathore, 2017). Penelitian Rathore (2017) menyebutkan mayoritas orang yang berkerja terlalu lama di depan gadget lebih dari 2 jam /hari akan mengalami gangguan dalam pengelihatan Penelitian lain menyebutkan bahwa 60 responden, $85 \%$ menyatakan mata lelah dan tegang, $60 \%$ mata teriritasi, $45 \%$ mata kabur, $45 \%$ nyeri kepala, $38 \%$ mata sakit dan mata berair, 30\% kesulitan memfokuskan pengelihatan, dan $23 \%$ pengelihatan ganda serta lama penggunaan smartphone lebih dari 4 jam sebanyak 33 responden yang menjadi faktor risiko terjadinya CVS dibandingkan dengan penggunaan smartphone yang kurang dari 4 jam (Azkadina, 2013)

Penggunaan gadget dalam durasi dan frekuensi yang berlebihan dan tidak terkontrol dapat berdampak negatif pada kesehatan mata yang akan menimbulkan berbagai macam keluhan seperti keluhan CVS. Berdasarkan hasil analisis hubungan intensitas penggunaan gadget dengan keluhan CVS didapatkan hasil signifikan yang menunjukan bahwa, keluhan CVS yang dirasakan disebabkan oleh lama penggunaan gadget pada remaja, dalam penelitian disebutkan faktor lain yang dapat mempengaruhi CVS, bukan hanya dari segi aspek stimulasi atau intensitas penggunaan gadget, tetapi juga dari fakor riwayat penyakit, biologis, fisik dan sosial (Argawal, 2013).

\section{SIMPULAN DAN SARAN}

Hasil penelitian menunjukkan sebagian besar responden memiliki tingkat intensitas penggunaan gadget sedang dan keluhan CVS dalam kategori sedang terdapat pula hubungan antara intensitas penggunaan gadget dengan keluhan CVS di SMPN 4 Denpasar. Dengan kekuatan hubungan sangat lemah dan arah hubungan positif, sehingga dapat diartikan bahwa semakin tinggi intensitas penggunaan gadget maka semakin tinggi keluhan CVS pada siswa-siswi di SMPN 4 Denpasar.

Diharapkan siswa-siswi sebagai pengguna gadget lebih bijaksana dalam menggunakan teknologi canggih ini guna untuk mengurangi masalah kesehatan yang berhubungan dengan mata salah satunya yaitu keluhan CVS. Bagi peneliti selanjutnya yang ingin melakukan penelitian dengan topik yang serupa, agar dapat mencari korelasi dari variabel-variabel lainnya seperti usia, jarak penggunaan dan riwayat penyakit, karena dalam penelitian ini variabelvariabel tersebut hanya digambarkan secara ringkas saja. Peneliti selanjutnya juga diharapkan agar dapat meminimalkan keterbatasan yang ada dalam penelitian ini.

\section{DAFTAR PUSTAKA}

Adriana, K.P., Rozalina, L., \& Djohar, N. (2018). Pengaruh penggunaan gadget terhadap penurunan kualitas pengelihatan siswa sekolah dasar. Global

$\begin{array}{ccc}\text { Medical } & \text { and } & \text { Health } \\ \text {. } & 6(1), & 33-38 . \\ \text { doi: } & & \end{array}$


http://dx.doi.org/10.29313/gmh c.v6i1.2471

Agarwal S, Goel D, Sharma A. (2013). Evaluation of the factors which contribute to the ocular complaints in computer users. $J$ Clin Diagn Res. 7(2):331-5.

Azkadina, A. (2012). Hubungan antara faktor risiko individual dan komputer terhadap kejadian computer vision syndrome. Skripsi. Semarang: Media Medika Muda.

Das B, Ghosh T. (2010). Assessment of ergonomical and occupational health related problems among vdt workers of West Bengal, India. Asian J Med Sci. 1.26-31.

Fahdian, R., Agus, T., \& Mansur, I. (2018). Analisis dampak pengguna gadget (smartphone) terhadap kepribadian dan karakter (KEKAR) peserta didik di sma negeri 9 malang. Jurnal Civic Hukum. 3(18), 43-65. Diakses dari: http://ejournal.umm.ac.id/

Horrigan, J.B. (2002). New Internet Users: What They Do Online, What They Don"t, and Implications for the "Net"s Future. Pew Internet and American Life Project pg. 1-27. Diakses dari: https://books.google.co.id

Manumpil, B., Ismanto, Y., \& Onibala, F. (2015). Hubungan penggunaan gadget dengan tingkat prestasi siswa di sma negeri 9 manado. E Journal Keperawatan(e-Kep). 3(2), 25.Diakses dari: http://repository.unpas.ac.id/
Ngafifi, M. (2014). Kemajuan teknologi dan pola hidup manusia dalam perspektif soaial budaya. Jurnal Pembangunan Pendidikan: Fondasi dan Aplikasi, 2(1), 2-4. Diakses dari: https://journal.uny.ac.id

Rathore, I. (2017). Computer vision Syndrome- An Emerging Occupational Hazzard. Research J. Science and Tech. 9(2). 